\title{
Livelihood and vulnerability analysis
}

\section{Charlie Shackleton, ${ }^{1}$ Kate Schreckenberg, ${ }^{2}$ Sheona Shackleton ${ }^{3}$ and Marty Luckert ${ }^{4}$}

${ }^{1}$ DEPARTMENT OF ENVIRONMENTAL SCIENCE, RHODES UNIVERSITY, MAKHANDA, SOUTH AFRICA

${ }^{2}$ READER IN DEVELOPMENT GEOGRAPHY, KING'S COLLEGE, LONDON, UK

${ }^{3}$ AFRICAN CLIMATE AND DEVELOPMENT INITIATIVE, UNIVERSITY OF CAPE TOWN, CAPE TOWN, SOUTH AFRICA ${ }^{4}$ DEPARTMENT OF RESOURCE ECONOMICS \& ENVIRONMENTAL SOCIOLOGY, UNIVERSITY OF ALBERTA, EDMONTON, CANADA

\section{Key methods discussed in this chapter}

Sustainable livelihood analysis, vulnerability analysis

\section{Connections to other chapters}

Livelihood analysis and vulnerability analysis are integrative approaches and consequently draw on a variety of methods to collect and analyse primary and secondary data covered in other chapters. Core ones include systems scoping (Chapter 5), ecological field data collection (Chapter 6), interviews and surveys (Chapter 7), participatory data collection (Chapter 8), action research (Chapter 15), statistical analysis (Chapter 18), qualitative content analysis (Chapter 19), comparative case study analysis (Chapter 20), institutional analysis (Chapter 22) and spatial mapping and analysis (Chapter 24).

\section{Introduction}

The origins of livelihood and vulnerability analyses can be traced back through a number of disciplines, each vested in subtly different ideologies and prescriptions about rural development and land use. Economists were interested in rural incomes and poverty outcomes through the use of land and the resources it produces; ecologists were concerned with the environmental sustainability of the same land and resources; sociologists sought to foster more equitable outcomes in terms of access to land and resources by different groups, genders and the power relations associated with these; and development planners considered strategies to simultaneously optimise land productivity, employment, markets and human development outcomes. Scoones (2009) outlines how the bridges between disciplines and ideologies evolved from the mid-1980s onwards towards more people-centred and 'holistic' policies and tools, laying the foundation for both livelihood analysis and vulnerability analysis.

Livelihood analysis concretised in the early 1990s with the appearance of the Chambers and Conway (1992) working paper. This paper provided the first definition of 'a livelihood' and when it is deemed sustainable, i.e. 'when it can cope with and recover from stresses and 


\section{SUMMARY TABLE: LIVELIHOOD AND VULNERABILITY ANALYSIS}

\begin{tabular}{|c|c|}
\hline DISCIPLINARY BACKGROUND & KNOWLEDGE TYPE \\
\hline $\begin{array}{l}\text { The methods in this chapter are derived } \\
\text { from or have most commonly been used in: } \\
\text { Interdisciplinary }\end{array}$ & $\begin{array}{l}\text { The methods in this chapter are primarily } \\
\text { used to generate the following types of } \\
\text { knowledge: } \\
\text { - Exploratory } \\
\text { - Explanatory }\end{array}$ \\
\hline RESEARCH APPROACH & PURPOSE OF METHOD \\
\hline $\begin{array}{l}\text { The methods in this chapter originate } \\
\text { from or most commonly adopt the } \\
\text { following research approaches: } \\
\text { - Analytical/objective } \\
\text { - Interpretive/subjective } \\
\text { - Collaborative/process }\end{array}$ & $\begin{array}{l}\text { The most common purposes of using the } \\
\text { methods in this chapter are: } \\
\text { - Data collection/generation } \\
\text { - Stakeholder engagement and co- } \\
\text { production } \\
\text { - Policy/decision support }\end{array}$ \\
\hline TEMPORAL DIMENSION & SYSTEMIC FEATURES AND PROCESSES \\
\hline $\begin{array}{l}\text { The methods in this chapter are most } \\
\text { commonly applied to the following } \\
\text { temporal dimensions: } \\
\text { - Present (typically within the last } \\
5-10 \text { years) } \\
\text { - Recent past (post-1700s) } \\
\text { - Future }\end{array}$ & \multirow{3}{*}{$\begin{array}{l}\text { While most methods can do many } \\
\text { things, the methods in this chapter are } \\
\text { particularly good (i.e. go-to methods) for } \\
\text { addressing the following: } \\
\text { - Diversity } \\
\text { - Social-ecological dependence } \\
\text { and impact } \\
\text { - Adaptation and self-organisation } \\
\text { - Evaluating policy options }\end{array}$} \\
\hline SPATIAL DIMENSION & \\
\hline $\begin{array}{l}\text { The methods in this chapter are primarily } \\
\text { either or both: } \\
\text { - Explicitly spatial } \\
\text { The methods in this chapter are most } \\
\text { commonly applied at the following } \\
\text { spatial scales: } \\
\text { - Local } \\
\text { - Multiple places/sites around the world }\end{array}$ & \\
\hline
\end{tabular}




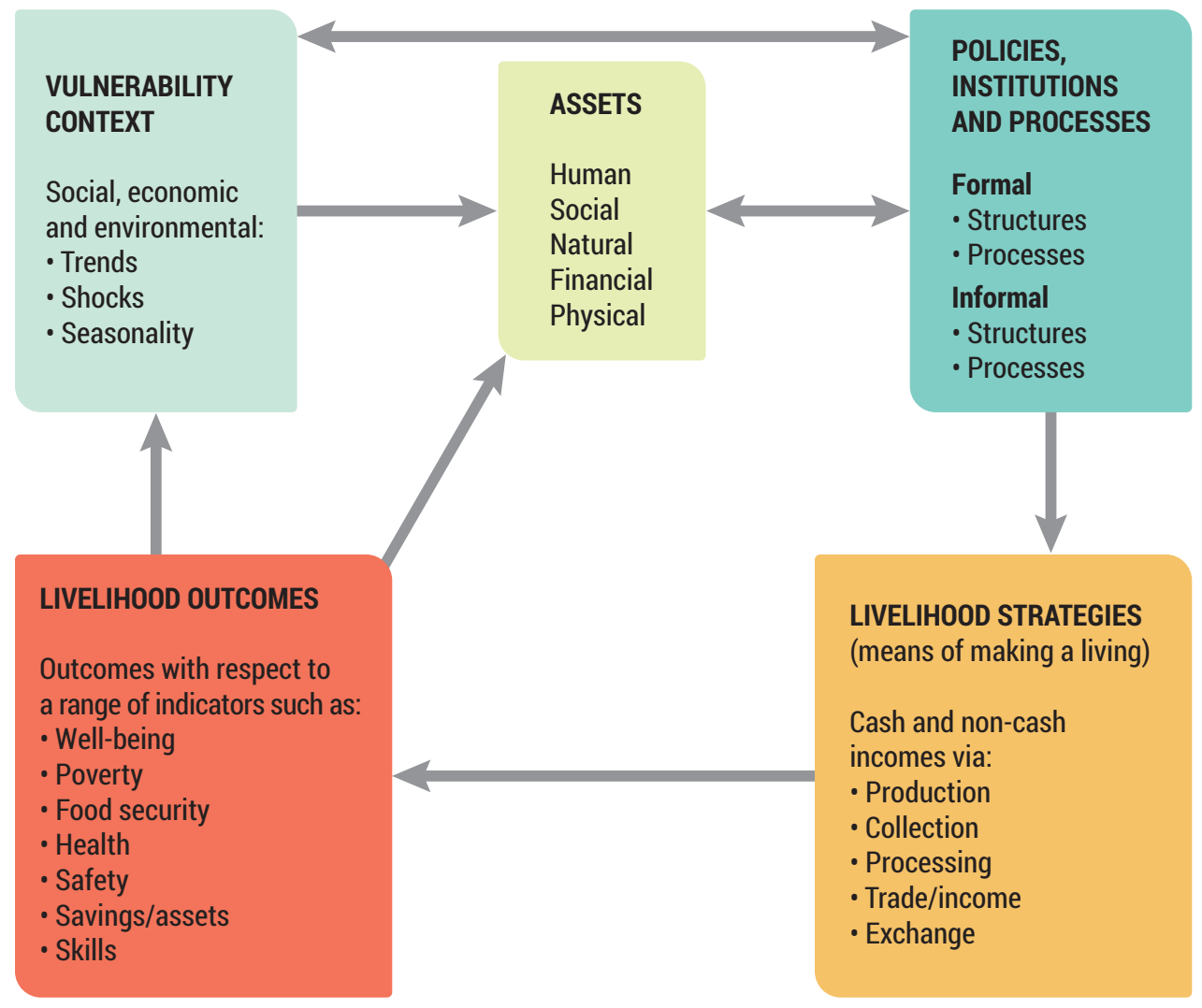

\section{ANALYSIS OF:}

\begin{tabular}{l|l}
$\begin{array}{l}\text { Vulnerability } \\
\text { context }\end{array}$ & Assets \\
$\begin{array}{l}\text { Current and } \\
\text { historical } \\
\text { conditions and } \\
\text { trends that }\end{array}$ & $\begin{array}{l}\text { of assets available to } \\
\text { specific households } \\
\text { or groups, and } \\
\text { trade-offs between } \\
\text { shape or } \\
\text { constrain }\end{array}$ \\
$\begin{array}{l}\text { them. Is the asset } \\
\text { options, } \\
\text { possibilities } \\
\text { and assets }\end{array}$ & $\begin{array}{l}\text { improving through } \\
\text { time or in response to } \\
\text { particular } \\
\text { interventions? Is the } \\
\text { asset base } \\
\text { accumulating or } \\
\text { eroding? }\end{array}$ \\
\hline
\end{tabular}

Policies,
institutions
and processes
The formal and
informal
institutions,
policies and
processes that
influence how
assets can or
cannot be used,
by whom, and
when

Livelihood
strategies
How people,
households or
groups use and
combine the
assets available
to them to earn
cash and
non-cash
incomes; how
and why they
mix them and
how and why
it changes
through time

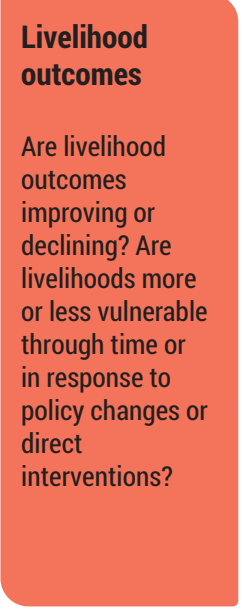

Figure 32.1 The sustainable livelihoods framework (adapted from the originals by Carney 1998 and Scoones 1998) ( Charlie Shackleton) 
shocks and maintain or enhance its capabilities and assets both now and in the future, while not undermining the natural resource base' (Carney 1998). Sallu, Twyman and Stringer (2010) point out that this aligns strongly with the current concepts of vulnerability and resilience. These early beginnings laid the foundation for the sustainable livelihoods framework (SLF) (Figure 32.1) to emerge a few years later, commonly depicted as an input-output model or diagram. The inputs were five asset classes and the outputs a suite of livelihood strategies that resulted in given livelihood outcomes in particular contexts, mediated by a range of local and higher-level institutions. Although it originated in response to rural development and poverty issues, the framework has also been found useful in urban settings (e.g. Farrington, Ramasut, and Walker 2002; Rakodi 2002).

Vulnerability analysis followed a similar trajectory of a merging of ideas and philosophies from multiple disciplines over a very similar period (Fuchs 2009). Adger (2006) describes how social, geographical and ecological scientists formed different schools that each applied this kind of analysis in their own way. However, there was a gradual and steady convergence and today it is difficult to conceive that there had ever been a separation. Most vulnerability analyses now consider both exposure to hazards and the underlying, often structural and contextual, factors or causes that make some groups or people more vulnerable to these hazards than others. In contrast to livelihood analysis, the multi-disciplinary parentage of vulnerability analysis has resulted in numerous vulnerability assessment frameworks and tools; some, but not all, of which emphasise either social or ecological aspects rather than the two simultaneously. Many of the widely applied participatory tools for human vulnerability analysis have been developed by practitioners in international NGOs concerned with assisting communities to adapt to climate change and its impacts (Füssel and Klein 2006). Increasingly, these tools are much more responsive to local context than more deductive index-based approaches (Vogel et al. 2007). Vulnerability analysis is also increasingly linked to notions of resilience (Vogel et al. 2007; Nguyen et al. 2016) because increased resilience more often than not results in reduced vulnerability.

There are strong commonalities and a sharing of core elements between sustainable livelihood analysis and most vulnerability analysis approaches (e.g. Fraser et al. 2011), including understanding livelihood activities, assets and access to these, institutions and multiple shocks and stresses. The evolution of sustainable livelihood analysis and vulnerability analysis as a merging of multiple disciplinary approaches to consider the diversity and complexity of rural lives and poverty predates and resonates with the development of social-ecological thinking and methods. These analyses are therefore particularly useful tools in social-ecological systems (SES) research dealing with important development and sustainability questions. Their core strengths of being people centred, context specific, local level, inter- and transdisciplinary, unequivocally linking people and the natural environment and explicitly recognising diversity and multiple outcomes, are widely sought in SES research.

\section{SES problems and questions}

Livelihood analysis and vulnerability analysis draw upon a wide diversity of qualitative and quantitative data-collection methods which provide the information necessary to understand how individuals, households and communities: (a) make a living, (b) generate cash and noncash incomes, (c) sustain themselves, their assets and networks within a given socio-economic and ecological context, (d) respond to short-term and long-term stressors and drivers, and (e) adapt to and cope with changing contexts and circumstances. These approaches seek to describe and analyse diversity among households and their members with respect to activities, 
assets, livelihood strategies and ultimately the livelihood outcomes, and pressures that shape vulnerability and sustainability.

The sustainable livelihoods approach and its associated sustainable livelihoods framework are widely used for organising data, information and insights obtained via multiple empirical methods to analyse the sustainability (or not) of current livelihoods. It differentiates livelihood strategies and livelihood outcomes. Livelihood strategies are the activities pursued to obtain cash and non-cash incomes and build the asset portfolio of the household or community, whereas livelihood outcomes are the ultimate benefits (or not) of engaging in a particular suite of strategies, such as increased well-being, reduced poverty or increased vulnerability. Understanding the vulnerability context of livelihoods is a core aspect of the sustainable livelihoods framework. However, there are also a host of more prescribed vulnerability assessment (vulnerability analysis) frameworks and tools (especially emerging from the climate change research field), which are applied independently of the sustainable livelihoods framework and that operate at varying scales, from global to local.

Sustainable livelihood analysis is useful in guiding a full and integrated analysis of the current situation regarding incomes and various 'capital' stocks that people can access and use. Common questions in sustainable livelihood analysis include:

- Who makes use of what natural resources in the local environment?

- Why?

- For what benefits?

- How is use or access controlled and by which institutions?

Questions about dynamics are also relevant, such as:

- How do households, particular groups or communities, cope or adapt in the face of temporary or longer-term changes in resource supply or access?

- How does livelihood diversification or trade-offs between strategies or between assets improve or undermine human well-being?

- How vulnerable are particular groups to specific stressors and how might that affect livelihood options and outcomes?

With respect to vulnerability analysis, questions of this nature can help to highlight the role of different natural resources in mediating some of the impacts of climate change on livelihoods. These questions can also reveal the potential for enhancing resilience through ecosystem-based adaptation.

\section{Brief description of key methods}

Both livelihood analysis and vulnerability analysis require holistic inter- and transdisciplinary perspectives and approaches. Methods and tools that provide data on the social, economic and ecological dimensions of livelihoods and vulnerability are required, e.g. household interviews, focus group discussions, oral narratives/histories (all in Chapter 7), participatory appraisal tools, e.g. seasonal calendars, timelines, resource and income ranking, participatory mapping, gender roles (Chapter 8), resource and ecological inventories (Chapter 6) and mapping (Chapter 24). Livelihood and vulnerability analysis may also include resource valuation, income determination, asset quantification, social network analysis, participatory modelling and planning, spatial analysis (for risk/ 
Table 32.1 Summary of key methods used in livelihood and vulnerability analysis

\begin{tabular}{|c|c|c|}
\hline Method & Description & References \\
\hline $\begin{array}{l}\text { Sustainable } \\
\text { livelihood } \\
\text { analysis }\end{array}$ & $\begin{array}{l}\text { Sustainable livelihood analysis is an } \\
\text { integrative analysis of the vulnerability } \\
\text { context, the institutions and the assets } \\
\text { available to groups of interest and how } \\
\text { these shape the livelihood strategies } \\
\text { adopted, and ultimately the livelihood } \\
\text { outcomes. }\end{array}$ & $\begin{array}{l}\text { Key introductory texts } \\
\text { Farrington et al. } 1999 \text { (ODI Natural } \\
\text { Resource Perspectives 42); } \\
\text { Serrat } 2008 \text { (Asian Development } \\
\text { Bank); } \\
\text { Valdés-Rodríguez and Pérez-Vázquez } \\
2011 \text { (Tropical and Subtropical } \\
\text { Agroecosystems 14) } \\
\text { Applications to SES } \\
\text { Campbell et al. 2002; } \\
\text { Sallu, Twyman, and Stringer 2010; } \\
\text { Masunungure and Shackleton 2018; } \\
\text { Östberg et al. } 2018\end{array}$ \\
\hline $\begin{array}{l}\text { Vulnerability } \\
\text { analysis }\end{array}$ & $\begin{array}{l}\text { Vulnerability analysis is primarily used to } \\
\text { determine the expected impacts, risks } \\
\text { and adaptive capacity of a region, sector, } \\
\text { social group or person to the effects of } \\
\text { climate change and other interacting } \\
\text { stresses. It involves several methods, from } \\
\text { indicator- or proxy-based methods to } \\
\text { geographic information systems (GIS) and } \\
\text { mapping, multiple-stressor-based methods, } \\
\text { participatory approaches, narratives } \\
\text { and stories, and household surveys. The } \\
\text { purpose of the assessment and scale } \\
\text { usually determines the type of method } \\
\text { used. There is no single 'best' approach or } \\
\text { method and all have their advantages and } \\
\text { disadvantages. } \\
\text { Participatory approaches have mainly been } \\
\text { developed and applied by international } \\
\text { NGOs such as CARE, the Red Cross, } \\
\text { ActionAid and Oxfam. Quantitative } \\
\text { approaches using indices are more in } \\
\text { the realm of economists. All approaches } \\
\text { should incorporate information on who/ } \\
\text { what is vulnerable to what (climate plus } \\
\text { other stressors) and when; the causes of } \\
\text { vulnerability across spatial and temporal } \\
\text { scales (causal models, problem trees); } \\
\text { factors influencing vulnerability outcomes } \\
\text { for what or whom (barriers, assets, } \\
\text { knowledge, policies and institutions - often } \\
\text { provided through livelihood analysis); } \\
\text { and actions or responses, including the } \\
\text { increasing vulnerability. }\end{array}$ & $\begin{array}{l}\text { Key introductory texts } \\
\text { Frameworks } \\
\text { Turner et al. 2003; } \\
\text { Schröter, Polsky, and Patt 2005; } \\
\text { Davis, Waagsaether, and } \\
\text { Methner } 2017 \\
\text { Tools and approaches (especially } \\
\text { participatory tools) } \\
\text { csir.co.za/documents/csir-global- } \\
\text { change-ebook.pdf; } \\
\text { letsrespondtoolkit.org/ } \\
\text { vulnerability-assessment; } \\
\text { mediation-project.eu/platform/tbox/ } \\
\text { participatory_vulnerability_and_- } \\
\text { capacity_assessments.html; } \\
\text { ifrc.org/Global/Publications/ } \\
\text { disasters/vca/vca-toolbox-en. } \\
\text { pdf (International Red Cross - } \\
\text { VAC_-vulnerability and capacity } \\
\text { assessment); } \\
\text { youtube.com/ } \\
\text { watch?v=Fv5vE2vxYwY; } \\
\text { actionaid.org.uk/sites/default/ } \\
\text { files/doc_lib/108_1_participatory_ } \\
\text { vulnerability_analysis_guide.pdf } \\
\text { (ActionAid UK) }\end{array}$ \\
\hline
\end{tabular}


vulnerability assessments), and composite indices of vulnerability, risk and coping strategies (e.g. food security measures). Table 32.1 provides a summary of key methods used in livelihood and vulnerability analysis.

\section{Limitations}

Given that the sustainable livelihoods framework is used by disciplinary and interdisciplinary researchers, it will inevitably not be able to meet all needs at all times. However, the nature and extent of certain assumptions related to or shortcomings of the framework are contested. The merits of the debates (and whether we agree with them or not) will not be considered here. Instead, we aim to make readers aware of some of the debates about the robustness or weaknesses of the sustainable livelihoods framework (Hobley 2001; Adato and MeinzenDick 2002; Bryceson 2002; Toner 2003; Serrat 2008; Morse, McNamara, and Acholo 2009; Scoones 2009), which they can investigate further if required.

The references in Table 32.1 cover the commentary on the sustainable livelihoods framework in terms of:

- Insufficient acknowledgement of power relations in the framework, especially political power, to the extent that some argue that power relations should be included as an additional asset class in the asset pentagon

\section{Case study 32.1: Livelihoods, change and vulnerability in rural Botswana}

Appreciating the nature of local livelihoods and the available assets households can draw on to construct their livelihoods is crucial in understanding broader patterns of poverty, social justice and whether development intervention or policies are required. It also provides insights into the efficacy of local institutions and household strategies in responding to shocks and vulnerability. These were the core concerns explored by Sallu, Twyman and Stringer (2010) in two villages in arid Botswana, when they sought to identify the factors that in 'isolation and combination push livelihoods along particular "trajectories" towards vulnerability or resilience'. Trends and livelihood trajectories were investigated over a 30-year period.

The researchers adopted a rich mixed-methods approach to gather the necessary information and data, including household questionnaires about livelihood activities and resources used, participatory time lines, oral histories, focus group discussions, vegetation and wild animal surveys, and analysis of remote-sensing images. The different methods allowed a substantive process of triangulation across findings. Qualitative data analysis was undertaken via thematic analysis and iterative reflexivity allowing for inductive interpretation. The more quantitative data were analysed using standard statistics.

The low rainfall and generally dystrophic, albeit patchy, soils at the two sites limited the types and intensity of some livelihood options, such as cropping. Livelihoods at both sites were significantly contingent on local landscapes and biodiversity resources. Thus, livestock husbandry and collection of non-timber forest products (such as wild foods, medicines and construction materials) were considered key livelihood 
- Its focus at the local level, which compromises its ability to be useful at higher spatial scales and in the face of global drivers of change

- Its strength in analysing the current, local-level situation, which results in a weakness for considering longer-term shifts in rural economies or institutions

- Its context-specific nature, which makes it hard to use in a comparative manner (and generalise across sites)

- The use of the words 'assets' and 'capitals', which embeds and overemphasises economic considerations

- The fact that markets are crucial to most rural livelihoods but are not explicit in the sustainable livelihoods framework

- The fact that the sustainable livelihoods framework is frequently erroneously reduced to just the asset pentagon, which makes it very difficult to operationalise as there is no single suite of accepted tools to do so

Some of the limitations of current vulnerability analysis approaches from an SES perspective relate to their (a) neglect of other livelihood stressors that may interact with climate hazards, (b) lack of attention to ecosystem health and ecosystem services delivery, (c) lack of clarity regarding which quantitative measures to select and apply from the large range used to date, and (d) neglect of scale issues and local context, and of social differentiation and intersectionality.

strategies for most households. However, households engaged in more than one livelihood strategy, such as small-scale cropping or vegetable gardening, hunting and small businesses around local needs, and a few had some form of salaried employment. Considering patterns across households, the researchers identified three broad clusters, which they labelled 'accumulators', 'diversifiers' and 'dependents'.

However, the broader environmental context had undergone marked changes over the previous 30 years, such that some livelihood strategies were no longer as successful as they used to be. Key contextual changes were: (a) an intense and prolonged drought in the mid-1980s, (b) the more frequent late onset of the rainy season, now approximately one month later than previously, (c) increased variability in the mean annual rainfall, (d) the loss of flood recession cultivation sites with the drying up of Lake Xau, and (e) land degradation. These translated into marked changes in livelihood strategies and outcomes for some households, and less so for others. Generally, an increase in household vulnerability was associated with a decline in or loss of one or more of the following: (a) access to local natural resources, (b) livestock, and (c) diversity of livelihood strategies. Households in the so-called 'dependent' cluster were the most vulnerable, followed by 'accumulators' if their primary livelihood strategy was placed at risk by changes in the local or broader context.

The study concluded that the findings had 'highlighted the importance of formal and informal institutions in building resilience and the need for increased effort to ensure [that] the most vulnerable households have access to a diversity of assets' (Sallu, Twyman, and Stringer 2010). Overall, the application of several quantitative and qualitative data-collection and analytical methods, framed within the current and historical context, allowed the researchers to develop deep insight into the livelihood trajectories and vulnerability of these village communities. 


\section{Resource implications}

Seeking to understand local livelihoods and vulnerability is resource intensive in terms of time (for focus group discussions, participatory exercises, household surveys, key informant interviews, mapping and resource inventories). These activities require sufficient budget for extended periods of field research to cover transport, field accommodation and supplies, local guides or assistants, and perhaps translators and interpreters. However, there is generally no need for expensive field equipment or sophisticated software. Some participatory mapping tools may require GIS or hardcopy aerial photographs. Otherwise, most data can be captured on field sheets or electronic devices or, if focus groups are held, on flipcharts. Videos and voice recorders can be useful but are not mandatory. As per the norm, refreshments should be served at group meetings that last longer than two hours. It may also be necessary to pay for the use of a particular venue and provide transport to the venue. Careful consideration must be given to research ethics because some people or households may engage in what are deemed by some regulatory authorities as illegal or undesirable activities (such a poaching, selling of protected species or use of land to which they don't have formal, recognised access).

Data analysis can take various forms depending on the precise research questions asked or emphasised, as well as the methods used. Quantitative surveys, for example, require different resources and skills than participatory data. For quantitative surveys, data access to and experience in using spreadsheets are useful. Depending on the objectives of the study, this could extend into statistical analysis using any of a number of software packages. Qualitative content analysis can be achieved via several different means such as thematic or content analysis, grounded theory, oral histories, narrative analysis and the like, depending on the researcher's theoretical or philosophical position (see Chapter 19). There is increasing use of software to assist in the analysis of qualitative data such as NVivo, Atlas.ti and QDA Miner.

\section{New directions}

Although livelihood analysis and vulnerability analysis have been around for a long time, these approaches and tools are being used in cutting-edge SES work, which fosters new applications and refinements of the tools themselves. Although five asset classes are integral to the sustainable livelihoods framework, most studies do not quantify each class equally but tend to focus on one or two more than the others. Historically, natural and financial capital have received the most attention, but there are renewed efforts regarding the development and application of indices of social or human capital. This is fostering some innovative uses of social network analysis within livelihood and vulnerability framings. Providing more equal attention to all asset classes reinvigorates debates about their substitutability.

Another key area is the application of the tools in longitudinal studies to better understand how livelihoods and vulnerability are changing and for whom, and what is driving the changes. This inevitably leads towards the merging of livelihood and vulnerability approaches with scenarios (Chapter 11). Furthermore, there is an increasing realisation of the need to disaggregate vulnerability assessments and livelihood strategies and outcomes between specific groups, such as by gender, by size of land holding, by wealth classes, by proximity to certain resources and so on. Livelihood and vulnerability approaches are also finding greater application in urban contexts in terms of urban residents' reliance on urban green infrastructure for a variety of capitals, or to cope with or develop resilience in times of heightened vulnerability. 


\section{Key readings}

Adger, W.N. 2006. 'Vulnerability.' Global Environmental Change, 16: 268-281.

Angelsen, A., H.O. Larsen, J.F. Lund, C. Smith-Hall, and S. Wunder. 2011. Measuring Livelihoods and Environmental Dependence: Methods for Research and Fieldwork. London: Earthscan.

De Lange, H.J., S. Sala, M. Vighi, and J.H. Faber. 2010. 'Ecological Vulnerability in Risk Assessment: A Review and Perspectives.' Science of the Total Environment 408: 3871-3879.

Scoones, I. 2009. 'Livelihoods Perspectives and Rural Development.' The Journal of Peasant Studies 36: 171-196.

Turner, B.L., R.E. Kasperson, P.A. Matsone, J. McCarthy, R.W. Corell, L. Christensen, N. Eckley et al. 2003. 'A Framework for Vulnerability Analysis in Sustainability Science.' Proceedings of the National Academy of Science 100: 8074-8079.

\section{Acknowledgements}

Charlie Shackleton's contribution was supported by the South African Research Chairs Initiative of the Department of Science and Innovation and the National Research Foundation of South Africa (grant 84379). Any opinion, finding, conclusion or recommendation expressed in this material is that of the authors and the NRF does not accept any liability in this regard.

\section{References}

Adato, M., and R. Meinzen-Dick. 2002. 'Assessing the Impact of Agricultural Research on Poverty Using the Sustainable Livelihoods Framework.' Environment and Production Technology Division Discussion Paper No. 89. Washington: International Food Policy Research Institute.

Adger, W.N. 2006. 'Vulnerability.' Global Environmental Change 16: 268-281.

Bryceson, D. 2002. 'Mutliplex Livelihoods in Rural Africa: Recasting the Terms and Conditions of Gainful Employment. Journal of Modern African Studies 40: 1-28.

Campbell, B.M., S. Jeffry, W. Kozanayi, M. Luckert, M. Mutamba, and C. Zindi. 2002. Household Livelihoods in Semi-arid Regions: Options and Constraints. Bogor: CIFOR.

Carney, D. 1998. 'Implementing the Sustainable Rural Livelihoods Approach.' In Sustainable Rural Livelihoods: What Contribution Can We Make? edited by D. Carney. London: DFID.

Chambers, R., and G. Conway. 1992. 'Sustainable Rural Livelihoods: Practical Concepts for the 21st Century.' IDS Discussion Paper, 296. Brighton: Institute of Development Studies.

Davis, C.L., K. Waagsaether, and N. Methner. 2017. 'Development of a Risk Assessment Methodology and Vulnerability Indices.' In Climate Change over South Africa: From Trends and Projected Changes to Vulnerability Assessments and the Status Quo of National Adaptation Strategies. South Africa's 3rd National Communication to UNFCCC. Pretoria: Department of Environmental Affairs. www.environment.gov.za/sites/default/files/reports/draftsouthafricas 3 rdnationalcommunicat ion_unfccc2017.pdf.

Farrington, J., D. Carney, C. Ashley, and C. Turton. 1999. 'Sustainable Livelihoods in Practice: Early Applications of Concepts in Rural Areas.' ODI Natural Resources Perspectives 42.

Farrington, J., T. Ramasut, and J. Walker. 2002. 'Sustainable Livelihoods Approaches in Urban Areas: General Lessons, with Illustrations from Indian Examples.' ODI Working Paper.

Fraser, E.D., A. Dougill, K. Hubacek, C. Quinn, J. Sendzimir, and M. Termansen. 2011. 'Assessing Vulnerability to Climate Change in Dryland Livelihood Systems: Conceptual Challenges and Interdisciplinary Solutions.' Ecology and Society 16(3): 3. doi:10.5751/ES-03402-160303.

Fuchs, S. 2009. 'Susceptibility versus Resilience in Mountain Hazards in Austria: Paradigms of Vulnerability Revisited.' Natural Hazards \& Earth Systems Science 9: 337-352.

Füssel, H-M., and R.J. Klein. 2006. 'Climate Change Vulnerability Assessments: An Evolution of Conceptual Thinking.' Climate Change 75: 301-329.

Hobley, M. 2001. Unpacking the PIP Box. Somerset: Hobley, Shields \& Associates.

Masunungure, C., and S.E. Shackleton. 2018. 'Exploring Long-term Livelihood and Landscape Change in Two Semi-arid Sites in Southern Africa: Drivers and Consequences for Social-Ecological Vulnerability.' Land 7(2): 50. doi:10.3390/land7020050. 
Morse, S., N. McNamara, and M. Acholo. 2009. 'Sustainable Livelihood Approach: A Critical Analysis of Theory and Practice.' Geographical Paper No. 189. Reading: University of Reading. www. reading.ac.uk/web/files/geographyandenvironmentalscience/GP189.pdf.

Nguyen, T.T., J. Bonetti, K. Rodgers, and C.D. Woodroffe. 2016. 'Indicator-based Assessment of Climate-change Impacts on Coasts: A Review of Concepts, Methodological Approaches and Vulnerability Indices.' Ocean and Coastal Management 123: 18-43.

Östberg, W., O. Howland, J. Mduma, and D. Brockington. 2018. 'Tracing Improving Livelihoods in Rural Africa Using Local Measures of Wealth: A Case Study from Central Tanzania, 1991-2016.' Land 7(2): 44. doi:10.3390/land7020044.

Rakodi, C. 2002. 'A Livelihoods Approach Conceptual Issues and Definitions.' In Urban Livelihoods: A People-centred Approach to Reducing Poverty, edited by C. Rakodi and T. Lloyd-Jones, 3-22. London: Earthscan.

Sallu, S.M., C. Twyman, and L.C. Stringer. 2010. 'Resilient or Vulnerable Livelihoods? Assessing Livelihood Dynamics and Trajectories in Rural Botswana.' Ecology \& Society 15(4): 3. www.ecologyand society.org/vol15/iss4/art3.

Schröter, D., C. Polsky, and A.G. Patt. 2005. 'Assessing Vulnerabilities to the Effects of Global Change: An Eight Step Approach.' Mitigation and Adaptation Strategies for Global Change 10: 573-596.

Scoones, I. 1998. 'Sustainable Rural Livelihoods: A Framework for Analysis.' Working Paper 72. Brighton: Institute for Development Studies.

Scoones, I. 2009. 'Livelihoods Perspectives and Rural Development.' The Journal of Peasant Studies 36: 171-196.

Serrat, O. 2008. 'The Sustainable Livelihoods Approach.' Knowledge Solutions. Manila: Asian Development Bank.

Toner, A. 2003. 'Exploring Sustainable Livelihoods Approaches in Relation to Two Interventions in Tanzania.' Journal of International Development 15: 771-781.

Turner, B.L., R.E. Kasperson, P.A. Matsone, J. McCarthy, R.W. Corell, L. Christensen, N. Eckley et al. 2003. 'A Framework for Vulnerability Analysis in Sustainability Science.' Proceedings of the National Academy of Science 100: 8074-8079.

Valdés-Rodríguez, O.A., and A. Pérez-Vázquez. 2011. 'Sustainable Livelihoods: An Analysis of the Methodology.' Tropical and Subtropical Agroecosystems 14: 91-99.

Vogel, C., S.C. Moser, R.E. Kasperson, and G.D. Dabelko. 2007. 'Linking Vulnerability, Adaptation and Resilience Science to Practice: Pathways, Players and Partnerships.' Global Environmental Change 17: 349-364. 